\title{
The exceptional one percent: U.S. farmworker and business owner
}

\author{
Michael J. Pisani ${ }^{\text {a* }}$ \\ Central Michigan University \\ Joseph M. Guzman ${ }^{\text {b }}$ \\ Michigan State University
}

Submitted September 8, 2015 / Revised October 31, 2015 / Accepted December 21, 2015 /

Published online February 29, 2016

Citation: Pisani, M. J., \& Guzman J. M. (2016). The exceptional one percent: U.S. farmworker and business owner. Journal of Agriculture, Food Systems, and Community Development, 6(2), 225-242. http://dx.doi.org/10.5304/jafscd.2016.062.015

Copyright (C) 2016 by New Leaf Associates, Inc.

\begin{abstract}
This paper documents the exceptional confluence between employment as a U.S. farmworker and business owner. Hispanics compose the overall majority $(79.7 \%)$ of U.S. farmworkers, with twothirds $(66.6 \%)$ of all farmworkers identifying as Mexican. Utilizing the National Agricultural Workers Survey conducted annually by the U.S. Department of Labor from 1989 to 2009, we
\end{abstract}

\footnotetext{
a * Corresponding author: Dr. Michael J. Pisani is professor of International Business and holder of the Jerry and Felicia Campbell Endowed Professorship for Research, Central Michigan University; 204C Smith Hall; Mt. Pleasant, Michigan 48859 USA; +1-989-774-3450; m.pisani@,cmich.edu

b Dr. Joseph M. Guzman, Assistant Professor, School of Human Resources \& Labor Relations and Interim Director, Chicano/Latino Studies Program, Michigan State University; South Kedzie Hall Room 200/414; 368 Farm Lane; East Lansing, Michigan 48824 USA; +1-517-353-8519; jguzman@msu.edu
}

explore the characteristics and determinants of these unique farmworker/business owners. Approximately 1\% (or about 10,000) U.S. farmworkers are business owners either in the U.S. or in their native homeland. Both Hispanics (53.0\%) and non-Hispanics (47.0\%) form this unique subset, although Hispanic farmworkers are underrepresented in this business owner subset given that they make up a relatively high proportion of all U.S. farmworkers. Implications for business growth, entrepreneurship, and economic development abound; even in the most trying of occupations entrepreneurial outcomes may emerge. Two case studies outline possible pathways to business formation for agricultural workers.

\section{Keywords}

farmworker, business owner, entrepreneurship, National Agricultural Workers Survey, NAWS, Latinos, Hispanics 


\section{Introduction}

The National Agricultural Workers Survey (NAWS), conducted annually by the U.S. Department of Labor, indicates that only one percent of U.S. agricultural workers in the period of 1989 to 2009 also owned their own business. With over one million agricultural workers in the U.S., there are approximately 10,000 farmworkers who are business owners either in the U.S. or in their country of origin, if the latter are cross-border agricultural workers. ${ }^{1}$ The phenomenon of agricultural work as a possible path to business ownership is understudied, especially the development from farmworker to business owner. Further, small business development in disadvantaged communities has long been the object of policymakers' attention. In this paper we focus on this "exceptional" one percent-those who are simultaneously agricultural workers and business owners - and examine the determinants of farmworker entrepreneurship using data from the NAWS gathered between 1989 and 2009 .

\section{Literature Review}

Shane and Venkataraman (2000) suggest that business owners or entrepreneurs are those individuals who are willing and able to make the most of market opportunities. Schumpeter (1911) and Kirzner (1973) refined our understanding of entrepreneurship to include punctuated innovations and the exploitation of incremental marketing openings. Holcombe (2008, p. 71) argues, "the engine of economic growth is not better inputs, but rather an environment in which entrepreneurial opportunities can be capitalized upon." Creating such an environment is a long-term public policy priority.

A select few agricultural workers, despite the arduous and seasonal nature of the work and generally low wages, are able to navigate the economic environment to own and operate a business enterprise. While there is no extant literature covering U.S. farmworkers who are also business

\footnotetext{
1 The NAWS labels cross-border agricultural workers-those workers who cross the U.S.-Mexico border in concert with U.S. agricultural harvest cycles_-as "international shuttlers." 2 The U.S. Census Bureau identifies Hispanic as "a person of Cuban, Mexican, Puerto Rican, South or Central American, or
}

owners, the NAWS notes that Hispanics ${ }^{2}$ compose the overall majority $(79.7 \%)$ of U.S. farmworkers, with two-thirds $(66.6 \%)$ of all farmworkers identifying as Mexican. Hence, a review of scholarship on Hispanic entrepreneurship may provide insights in the absence of a literature on U.S. farmworkers as business owners.

\section{Rural Hispanic Self-Employment}

Refugio Rochín and colleagues (Rochín, Saenz, Hampton, \& Calo, 1998) have examined rural Latino $^{3}$ self-employment in California. Rochín notes that structural conditions (e.g., high unemployment, limited educational attainment, and high concentration of agricultural workers) heavily influence self-employment outcomes, resulting in Latinos being "self-employed as part of their own means for survival” (Rochín, 2013, p. 89). In her study of rural Latino entrepreneurs in California using U.S. census data, Calo (1995) found an overall Latino self-employment rate of $9.0 \%$ (about 51,000 individuals), with just over one-third (35.8\%) of self-employed rural Latinos also earning a wage income. Calo (1995) also noted that selfemployed Latinos are engaged in a few sectors, including agriculture $(29.2 \%)$, personal, entertainment, and professional services (25.9\%), business and repair services $(21.8 \%)$, wholesale and retail trade (14.5\%), and construction (12.0\%). Lastly, Calo (1995) reports that self-employed Latinos with supplemental wage income earn 29.2\% more than self-employed Latinos without additional wage income. Hence, Rochín and colleagues suggest a connection between wage income such as farmworker earnings and self-employment, although Calo (1995) suggests that more work needs to be done with regard to dual enrollment in self-employment and wage employment.

\section{Latino Entrepreneurship}

While the literature on Latino entrepreneurship is in its infancy, there are a handful of studies that

other Spanish culture or origin regardless of race" (U.S. Census Bureau, 2011, p. 2).

${ }^{3}$ Following the Pew Hispanic Center (Lopez, 2013), we use the terms Hispanic and Latino interchangeably. 
help shape the current state of knowledge. Because of the ongoing flow of immigration from Mexico and other sending countries, enclave or immigrant community entrepreneurship has been a sustained focus of study. Portes and Haller (2005), Light (2005), Malkin (2004), and Striffler (2007) examined different immigrant groups in the U.S. and found that successful immigrant communities offer newly arrived co-ethnics help in securing informal sources of credit, insurance, child support, English language training, job referrals, job placement, support networks, and employment assistance (including self-employment assistance). More generally, Calo (1995) uncovered direct relationships between Latino self-employment and greater educational attainment, higher English proficiency, additional work experience, and Latino population enclaves.

Four studies have reviewed urban Latino entrepreneurship in Las Vegas, Chicago, Washington, D.C., and Virginia. Shinnar and Young (2008) found that Latino self-employment in Las Vegas was more a result of available business opportunities than a necessity of securing some income source, though both were important motivations in start-up decisions. In their study of "Little Village" in Chicago, Tienda and Raijman (2004) noted a stepladder approach to Latino business ownership, where informal markets are an important ingredient in initiating and scaling enterprises. Verdaguer (2009) focused on Salvadoran and Peruvian Latino entrepreneurs in the metropolitan Washington, D.C., area. Noting different trajectories and resource bases of Salvdorans and Peruvians, Verdaguer (2009) found heterogeneity in entrepreneurship endeavors and outcomes, and cautions against sweeping pan-ethnic descriptions where differences among different Hispanic origin groups may be profound. ${ }^{4}$ In her study of Harrisonburg, Virginia, Zarrugh (2007) uncovered an enclave of Latino self-employment as a response to blocked employment paths, partially a result of racism. This result is supported by Dávila and Mora (2013), who

\footnotetext{
${ }^{4}$ By design, Verdaguer (2009) studied the common and disparate threads between Peruvian and Salvadoran entrepreneurs in the Washington, D.C., area. In this present research, while the agricultural workers are predominately of Mexican origin,
}

also noted that this is especially true for Hispanic immigrant entrepreneurs. National studies suggest that Latina entrepreneurs earn more than similar non-Latina (Anglo) entrepreneurs, but still earn less than similar Latinas who receive wages and/or salaries (Lofstrom \& Bates, 2009). Wang and Li (2007) argue that English language ability is a determinant of self-employment for Latinos, and Borjas and Katz (2007) suggest that Latinos improve their earnings over time.

Latino entrepreneurship also finds its way into the large undocumented population in the U.S., where approximately $75 \%$ of the estimated 11.2 million without documentation are Latino (Passel \& Cohn, 2014). Because the undocumented earn income while trying to avoid governmental detection, one potential employment source is informal self-employment. Informal enterprises are businesses operating outside the purview of government oversight, yet these business concerns operate in such a way that the business itself could be conducted within the bounds of government regulation. While not picked up in official surveys of businesses, these enterprises do exist and require qualitative study. Pisani (2012) highlights the experience of undocumented Latinos owning and operating informal businesses in South Texas, ${ }^{5}$ primarily a result of insufficient immigration documentation and work authorization. To remain undetected, these businesses often engage in the low-profile occupations of domestic workers, tradesmen, landscapers, or small-volume vendors.

\section{Data and Methodology}

The NAWS, commissioned yearly by the U.S. Department of Agriculture and conducted by the Department of Labor, selects field workers engaged in crop agriculture to be interviewed through a random sample of agricultural employers in the continental U.S. Following the seasonal nature of agriculture, interviews are conducted three times per year, in February, June, and October, across 12 geographical regions, with the

this group is not homogenous, allowing for more nuanced examination reflected in the analysis that follows.

${ }^{5}$ South Texas is also a magnet for informality; see Richardson and Pisani (2012) for a more detailed review. 
number interviewed proportional to the estimated seasonal farm labor flow. Participation rates are relatively high; for example, the 2009 survey had an employer response rate of $66 \%$ and agricultural worker response rate of $92 \%$, aided by a US $\$ 20$ honorarium for participation in the hour-long survey (U.S. Department of Labor, n.d.-a).

We utilize the NAWS $^{6}$ public access data for the years 1989 through 2009 containing blinded interview data from 52,479 agriculture workers. ${ }^{7}$ The data set is composed of pooled cross-sectional data. On average about 2,500 agricultural workers, limited to hired crop farmworkers (or a large subset of all agricultural workers), were interviewed yearly, with 1,511 interviewed in 2007 and 3,612 interviewed in 1999. The NAWS provides sample weights for comparison purposes across years of the survey. The questionnaire contains sections covering the household roster, demographics, and living conditions; health, sanitation, and insurance; government assistance; education and training; language acquisition and usage; work history, employment, and migration with an agricultural focus; income and other assets; pesticide use; and legal status. The NAWS "data set includes 220 questionnaire variables and 100 created variables" (U.S. Department of Labor, n.d.-b, p. 1).

The dependent variable of business ownership in this study is derived from two yes or no NAWS survey questions: (1) "Do you own or are you buying the following item in the United States? A business"; and (2) "Do you own or are you buying the following item in your home country? A

\footnotetext{
${ }^{6}$ Several researchers have utilized the NAWS data to examine specific areas of agricultural worker activities — including pay (Isé \& Perloff, 1995; Kandilov \& Kandilov (2010), health care (Hoerster, Beddawi, Peddecord, \& Ayala, 2010), working conditions (Kandel \& Donato, 2009; Pena, 2012, 2014) and worker contracts (Pena, 2010)- all contributing to the robustness of the NAWS as a research source.

${ }^{7}$ While it is remotely possible that the same agricultural worker could be interviewed more than once in the sample time frame (1989-2009), it is highly unlikely. First, the NAWS prohibits re-interviewing of respondents within a 12-month period. Second, the annual random selection of approximately 2,500 agricultural workers to interview from a pool of more than 1 million agricultural workers suggests a less than $0.3 \%$ chance of being selected for an interview in a given year.
}

business." Throughout the study period, 500 agriculture fieldworkers identified as owning a business either in the U.S. $(n=347)$ or in their home country outside the U.S. $(n=153) .^{8}$ We will refer to this enterprising 500 subgroup as "the exceptional one percent," as they make up that percentage of the total 52,063 respondents. There are no follow-up questions in the NAWS as to the type of business or other business characteristics.

The selection of independent variables is derived from the literature on Hispanic entrepreneurship, including the importance of gender, years of experience (e.g., age, agricultural work experience, and migrant work experience, including cross-border shuttling), interview location (East, Southeast, Midwest, Southwest, Northwest, ${ }^{9}$ or California), educational achievement, nativity (i.e., birthplace), ethnicity (Hispanic or non-Hispanic), immigration status (e.g., U.S. citizen, U.S. green card holder, other U.S. work authorization, unauthorized), English proficiency (e.g., ability, usage), and available resources (e.g., personal and household income). One additional variable, civil (or marital) status, was also included as an independent variable.

As the dependent variable is dichotomous (i.e., business ownership and/or buying a business ["yes" or "no"] at time of the survey), we conducted a binary logistic regression to estimate the likelihood of business ownership. Use of binary logistic regression as a statistical technique is appropriate when there are multiple independent variables and the dependent variable is discrete (i.e., there are two choices: own a business/do not

\footnotetext{
${ }^{8}$ Only one respondent indicated owning a business both in the U.S. and in his home country (identified as the Pacific Islands). Critical missing data, including income, resulted in this respondent (from 1989) being dropped from the multivariate analyses.

${ }^{9}$ The regions are composed of the following states: East: Connecticut, Kentucky, Maine, Massachusetts, New Hampshire, New York, North Carolina, Rhode Island, Vermont, Virginia, West Virginia; Southeast: Alabama, Arkansas, Florida, Georgia, Louisiana, Mississippi, South Carolina; Midwest: Illinois, Indiana, Iowa, Kansas, Michigan, Minnesota, Missouri, Nebraska, North Dakota, Ohio, South Dakota, Wisconsin; Southwest: Arizona, New Mexico, Oklahoma, Texas; Northwest: Colorado, Idaho, Montana, Nevada, Oregon, Utah, Washington, Wyoming; and California.
} 
own a business). The advantages of logistic regression are many, including estimating the probability of such an event-in the present case, agricultural workers owning a business - to occur under relaxed assumptions. ${ }^{10}$ In its basic form, this model allows us to identify the factors that determine business ownership for agricultural workers. Our results follow.

\section{Results}

In this section, we report on the descriptive statistics for farmworker and business owner and for farmworkers in the NAWS sample over the period 1989-2009. Next we estimate the determinants of farmworker business ownership. We follow this with a further examination of the determinants of farmworker and business owner by location of business, either in the U.S. or home country. This section concludes with a discussion of the results presented.
Examination of Farmworkers and Business Owners For ease of exposition, respondents who are farmworkers and businesses owners will be referred to as "business owners," and farmworkers who are not business owners will be referred to as "farmworkers." While business owners appear in each year of the survey, the 1989 to 1994 period has the most respondents identifying as business owners, a likely result of the regularization of immigration status after the implementation of the Immigration Reform and Control Act (IRCA) of 1986 (see Figure 1). ${ }^{11}$ Table 1 reports the descriptive statistics for business owners vis-à-vis the remainder of the farmworker sample. The independent variables distinguish the two subsets, all of which are statistically different between the two groups, as examined below.

While men are the majority in both groups, women form a higher percentage of business owners $(35.4 \%)$ as compared to farmworkers $(22.3 \%)$.

Figure 1. Number of U.S. Farmworkers Who Own or Are Buying a Business by Year, 1989-2009

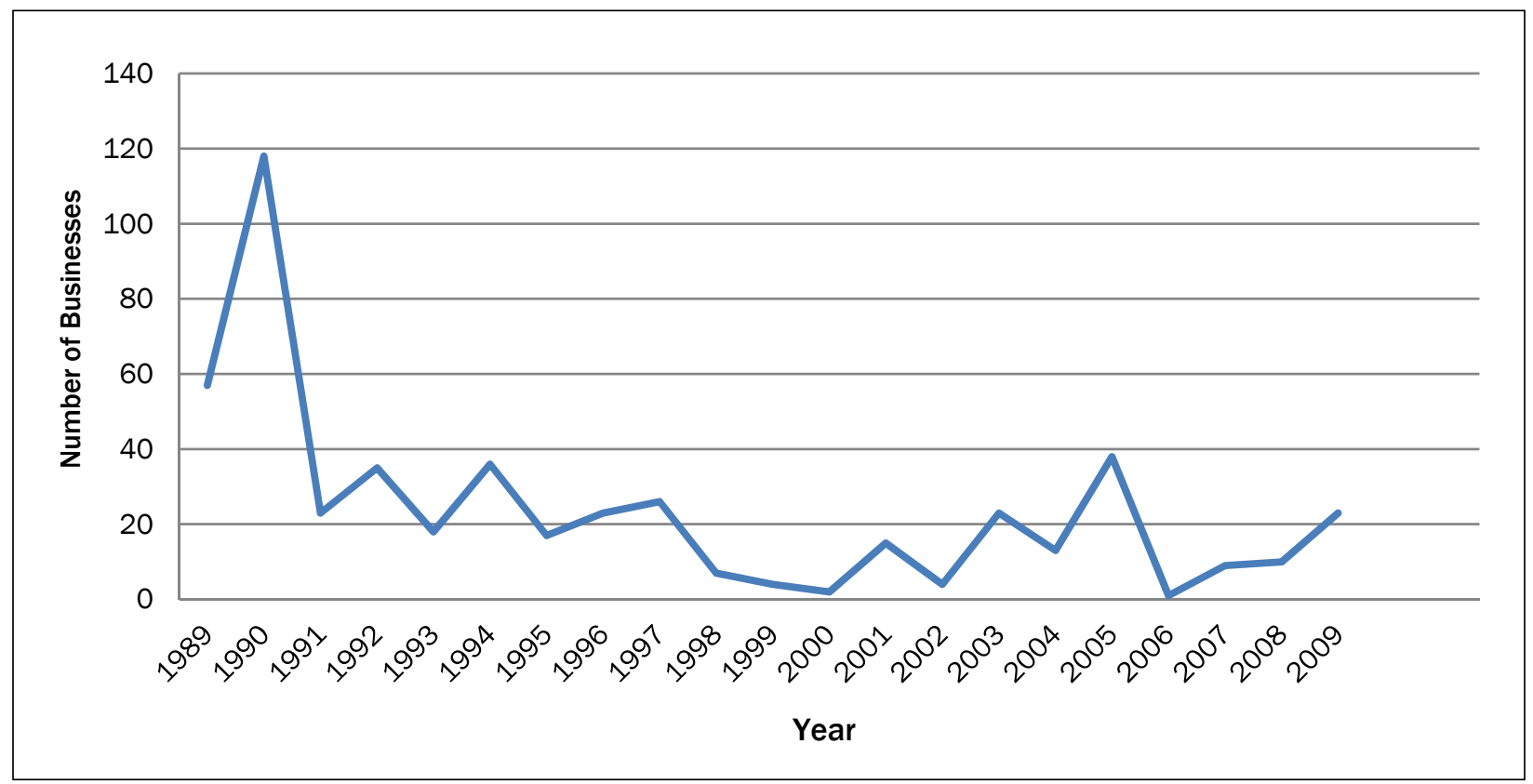

Source: Authors' calculation from the National Agricultural Workers Survey, 1989-2009.

\footnotetext{
${ }^{10}$ Logistic regression is a robust statistical tool, in part because estimation does not require the following assumptions: a linear relationship between the dependent and independent variables, independent variables to be multivariate normal, independent variables be metrically scaled, or homogeneity of variance.
}

Further, the method of estimation is maximum likelihood and yields values for the unknown parameters that maximize the probability of obtaining the observed set of data.

11 The year count is significantly different across the years; cross-tabulation: Pearson Chi-Square $=58.266, \mathrm{df}=20, p=.000$. 
Business owners on average are older (38.6 years of age versus 32.6 years of age) and more likely to be married than farmworkers $(71.3 \%$ versus $55.0 \%$, respectively). While Hispanics make up the majority $(53.1 \%)$ of business owners, half $(50.4 \%)$ of business owners were born in the U.S., as compared to one-quarter of farmworkers who were born in the U.S. Mexico is heavily represented as a place of birth for both groups: a majority $(68.2 \%)$ of farmworkers were born in Mexico and almost half $(44.6 \%)$ of business owners were born in Mexico. In conjunction with place of birth, two-thirds $(66.1 \%)$ of business owners are U.S. citizens or green card holders and less than onefourth (23.1\%) are unauthorized to be in the U.S. In contrast, $42.8 \%$ of farmworkers are unauthorized to be in the U.S. and just over half (50.8\%) possess U.S. citizenship or a green card.
Table 1. U.S. Farmworker Descriptive Statistics at Time of Survey (1989-2009)

\begin{tabular}{|c|c|c|}
\hline Variable & $\begin{array}{c}\text { Business Owners } \\
\text { (U.S. \& Home Country) }\end{array}$ & Farmworkers \\
\hline \multicolumn{3}{|l|}{ Gender (\%) } \\
\hline Male & 64.6 & 77.7 \\
\hline Female & 35.4 & 22.3 \\
\hline Mean Age (std. dev.) & $38.6(12.3)$ & $32.6(12.5)$ \\
\hline \multicolumn{3}{|l|}{ Civil Status (\%) } \\
\hline Single & 25.3 & 39.6 \\
\hline Married/Living Together & 71.3 & 55.0 \\
\hline Divorced/Separated/Widowed & 3.4 & 5.3 \\
\hline \multicolumn{3}{|l|}{ Birthplace (\%) } \\
\hline U.S. & 50.4 & 25.7 \\
\hline Puerto Rico & 1.0 & 1.6 \\
\hline Mexico & 44.6 & 68.2 \\
\hline Central America & 2.4 & 2.9 \\
\hline Other & 1.6 & 1.6 \\
\hline \multicolumn{3}{|l|}{ Education-Highest Grade Level Completed (\%) } \\
\hline None & 1.6 & 4.8 \\
\hline Elementary (1-6 grades) & 26.0 & 44.4 \\
\hline Middle School (7-9 grades) & 12.6 & 20.2 \\
\hline Some High School (10-11 grades) & 12.8 & 9.5 \\
\hline High School (12 grades) & 26.9 & 15.2 \\
\hline Some College and Beyond & 20.1 & 5.9 \\
\hline International Shuttler-Yes (\%) & 21.4 & 28.9 \\
\hline Migrant Farmworker-Yes (\%) & 32.4 & 43.4 \\
\hline Hispanic-Yes (\%) & 53.1 & 80.0 \\
\hline \multicolumn{3}{|l|}{ Speak English (\%) } \\
\hline Not at all & 20.4 & 40.0 \\
\hline A little & 23.0 & 28.1 \\
\hline Somewhat & 7.1 & 7.6 \\
\hline Well & 49.5 & 23.9 \\
\hline \multicolumn{3}{|l|}{ Read English (\%) } \\
\hline Not at all & 26.4 & 47.9 \\
\hline A little & 12.8 & 19.9 \\
\hline Somewhat & 3.4 & 5.7 \\
\hline Well & 57.3 & 26.5 \\
\hline \multicolumn{3}{|l|}{ Language Most Comfortable Conversing In... (\%) } \\
\hline English & 50.0 & 22.2 \\
\hline Spanish & 46.6 & 75.1 \\
\hline Other & 3.4 & 2.7 \\
\hline Mean Years Worked on the Farm in the U.S. (std. dev.) & $12.7(11.9)$ & $9.7(9.9)$ \\
\hline \multicolumn{3}{|l|}{ Interview Region (\%) } \\
\hline East & 22.4 & 16.3 \\
\hline Southeast & 17.2 & 14.2 \\
\hline Midwest & 36.5 & 19.5 \\
\hline Southwest & 2.2 & 7.6 \\
\hline Northwest & 11.2 & 12.0 \\
\hline California & 10.6 & 30.5 \\
\hline \multicolumn{3}{|l|}{ Adjusted Income (in 2009 U.S. dollars) } \\
\hline Mean Personal Income (std. dev.) & $18,591(17,272)$ & $13,167(9,186)$ \\
\hline Mean Family Income (std. dev.) & $28,727(21,634)$ & $18,866(14,716)$ \\
\hline \multicolumn{3}{|l|}{ U.S. Immigration Status (\%) } \\
\hline U.S. Citizen & 53.8 & 29.9 \\
\hline U.S. Green Card & 12.3 & 20.9 \\
\hline Other Work Authorization & 10.7 & 6.4 \\
\hline Unauthorized & 23.1 & 42.8 \\
\hline Weighted $N$ & 500 & 52,063 \\
\hline
\end{tabular}

Italics=Statistically different at the .001 level.

Source: Authors' calculation from National Agricultural Workers Survey, 1989-2009. 
Nearly half of business owners are high school graduates or have studied at college, in contrast nearly half of farmworkers possess no education or an elementary school education. Large numbers of both groups migrate to work on the farm and shuttle across international borders to do so; however farmworkers do so in larger numbers $(28.9 \%$ vs. $21.4 \%$, respectively). With respect to language facility, more than half of business owners are able to communicate (oral and written) in English and half $(50.0 \%)$ feel most comfortable communicating in English. On the other hand, Spanish is the predominant language of choice $(75.1 \%)$ for farmworkers with less than one-third able to communicate in English. Business owners have also worked on average longer on the farm in the U.S. than farmworkers (12.7 years versus 9.7 years, respectively). There is a disparity in incomes between the two groups; business owners earn $41 \%$ and $52 \%$ more as individuals and households, respectively. Lastly, the following interview regions are overrepresented with respect to business owners: East, Southeast, and the Midwest (ranging from $17.2 \%$ to $36.5 \%$ ). Conversely, the Southwest had by far the lowest business owner representation $(2.2 \%)$.

To better understand which variables are significant in determining which U.S. farmworkers own a business, we employed a logistic regression model utilizing the NAWS data set to estimate the determinates of business ownership among farmworkers (see Table 2). Business ownership served as the dichotomous dependent variable (business owner $=1$, farmworker only $=0$ ). Because of missing data, three logistic regression models were utilized using the available independent variables. Model 1 contains 7 variables (gender, age, civil status, birthplace, education level, international shuttler [i.e., does respondent cross the international border in order to engage in U.S. farm work, yes $=1$,

\footnotetext{
${ }^{12}$ Logistic regression diagnostics across all three models are acceptable.

13 This rate is calculated as $1-\beta$ from Table 2 (for this example, see column $2,1.487-1$ or .487 and $1.350-1$ or .350). In Table 2, symbols attached to the first listing of categorical variables with reference categories indicate the variable is significant; see for example row 5 civil status.

14 More specifically, odds of those with an elementary school
}

otherwise $=0$ ], and region of interview) and includes 499 of $500(99.8 \%)$ business owners. Model 2 contains the 7 variables identified in model 1 and 5 additional variables (migrant farm work status, ethnicity [Hispanic $=1$, otherwise $=0$ ], language most comfortable conversing in, number of years worked on the farm in the U.S., and immigration status) and includes 439 of 500 (87.8\%) business owners. Model 3 contains the 12 variables identified in model 2 and 4 additional variables (English speaking ability, English reading ability, annual personal income, annual family [household] income) and includes 277 of 500 (55.4\%) business owners.

\section{Results of Model 1}

In model 1, which includes $99.8 \%$ of the business owner sample, all variables but birthplace are significant in differentiating the odds of business ownership and non-business ownership among U.S. farmworkers. ${ }^{12}$ All of the significant independent variables in model 1 increase the odds of business ownership. The odds that males are business owners are $48.7 \%$ higher than females, and the odds that international shuttlers are business owners are $35.0 \%$ greater than non-shuttlers. ${ }^{13}$ Furthermore, each additional year of age increases the odds of business ownership by $3.4 \%$; being married increases the odds of business ownership by $74.7 \%$ over those who are single; and all schooling enhances the odds of business ownership, with greater amounts of education increasing the odds at each education step. ${ }^{14}$ Lastly, residence in all regions except the Southwest are more likely to increase the odds of business ownership compared to those respondents from California (ranging from 1.2 to 2.6 times).

\section{Results of Model 2}

Model 2 extends the variables under consideration

education are 1.6 times greater to own a business than those farmworker respondents with no education. Additional schooling results increase the odds of business ownership at the following rates: 1.2 times for middle school, 5.9 times for some high school, 6.3 times for high school, and 12.7 times for some college or beyond when compared to those with no education. 
in Model 1, but in doing so loses

$12.0 \%$ of the model 1 sample due to missing data.

Nevertheless, the results in Model 2 for gender, age, civil status, education, international shuttling, and interview region are very similar to Model 1 results. For brevity of exposition, see Model 1 and the aforementioned variables as the results parallel the earlier discussion. Model 2 also adds new significant insights with regard to birthplace, migrant work, language preference, years worked on the farm in the U.S., and immigration status. Reducing the odds of business ownership by $81.0 \%$ is nativity outside of Mexico and Central America in reference to nativity in the U.S. Correspondingly, preference for conversing in Spanish rather than English decreases the odds of business ownership by $48.0 \%$. On the other hand, status as a migrant farmworker decreases the odds of
Table 2. Logistic Regression Results (Odds Ratios) for Farmworker Business Ownership (Business Owner=1)

\begin{tabular}{|c|c|c|c|}
\hline Variable & $\begin{array}{c}\text { Model 1 } \\
\operatorname{Exp}(\beta)\end{array}$ & $\begin{array}{c}\text { Model } 2 \\
\operatorname{Exp}(\beta)\end{array}$ & $\begin{array}{c}\text { Model } 3 \\
\operatorname{Exp}(\beta)\end{array}$ \\
\hline Gender (Male=1) a & $1.487 \ddagger$ & $1.660 \ddagger$ & 1.383† \\
\hline Age (Years) & $1.034 \ddagger$ & $1.030 \ddagger$ & $1.028 \ddagger$ \\
\hline Civil Status & $--\ddagger$ & $--\ddagger$ & $--\ddagger$ \\
\hline Married/Living Together & $1.747 \ddagger$ & $1.744 \ddagger$ & $2.167 \ddagger$ \\
\hline Separated/Divorced/Widowed & .648 & .806 & 1.599 \\
\hline Birthplace & --- & $---\dagger$ & $--*$ \\
\hline Mexico & 1.171 & 1.845 & 1.669 \\
\hline Central America & 1.451 & 1.874 & 1.362 \\
\hline Other & .784 & $.190 *$ & $.157 *$ \\
\hline Education & $--\ddagger$ & $--\ddagger$ & $--\ddagger$ \\
\hline Elementary $(1-6)$ & $2.600 \dagger$ & $3.067 \ddagger$ & 1.629 \\
\hline Middle School (7-9) & $3.212 \ddagger$ & 3.321‡ & 1.917 \\
\hline Some High School (10-11) & $6.939 \ddagger$ & $6.481 \ddagger$ & $2.234 *$ \\
\hline High School (12 grades) & 7.336‡ & $6.538 \neq$ & 1.588 \\
\hline Some College and Beyond & $13.694 \ddagger$ & $13.196 \ddagger$ & $3.878 \ddagger$ \\
\hline International Shuttler (Yes=1) & $1.350 \dagger$ & $1.723 \ddagger$ & 1.426 \\
\hline Migrant Farmworker (Yes=1) & - & $.726^{*}$ & 1.089 \\
\hline Hispanic (Yes=1) & - & .829 & .844 \\
\hline Speak English & - & - & $--\ddagger$ \\
\hline A little & - & - & $1.800 \ddagger$ \\
\hline Somewhat & - & - & $2.209 \ddagger$ \\
\hline Well & - & - & .895 \\
\hline Read English & - & - & $--\ddagger$ \\
\hline A little & - & - & .745 \\
\hline Somewhat & - & - & .685 \\
\hline Well & - & - & $6.044 \ddagger$ \\
\hline Language Most Comfortable Conversing In... & - & $--\ddagger$ & --‡ \\
\hline Spanish & - & $.520 *$ & 1.188 \\
\hline Other & - & 1.458 & $4.060 \ddagger$ \\
\hline Years Worked on the Farm in the U.S. & - & $1.012 \dagger$ & .992 \\
\hline Interview Region & $---\ddagger$ & $--\ddagger$ & $--\ddagger$ \\
\hline East & $3.258 \ddagger$ & $4.045 \ddagger$ & $3.298 \ddagger$ \\
\hline Southeast & $3.304 \ddagger$ & $2.912 \ddagger$ & $2.588 \ddagger$ \\
\hline Midwest & $3.639 \ddagger$ & $3.867 \ddagger$ & $2.653 \ddagger$ \\
\hline Southwest & .709 & .838 & .852 \\
\hline Northwest & $2.191 \ddagger$ & $2.434 \ddagger$ & $1.708 \ddagger$ \\
\hline Personal Income & - & - & $1.000 \ddagger$ \\
\hline Family Income & - & - & 1.000 \\
\hline U.S. Immigration Status & - & $--\ddagger$ & $--\ddagger$ \\
\hline U.S. Green Card & - & .973 & 1.494 \\
\hline Other Work Authorization & - & $3.603 \ddagger$ & $6.021 \ddagger$ \\
\hline Unauthorized & - & 1.221 & 2.057 \\
\hline Weighted N: Own/Buying a Business | Other & 499 | 51,331 & $439 \mid 48,622$ & $277 \mid 34,980$ \\
\hline $\begin{array}{l}\text { Model Diagnostics -2LL } \\
\end{array}$ & 5115.984 & 4487.832 & 2855.301 \\
\hline $\mathrm{X}^{2}$ & 508.769‡ & 529.609‡ & $381.492 \ddagger$ \\
\hline Cox \& Snell R2 & .010 & .011 & .011 \\
\hline Nagelkerke R2 & .095 & .110 & .123 \\
\hline
\end{tabular}

a Reference categories: Gender=Male, Civil Status=Single; Birthplace=Born in USA/Puerto Rico;

Education=None; International Shuttler=Yes; Hispanic=Yes; Speak English=Not at all; Read English=Not at all; Language Most Comfortable Conversing in=English; Interview Region=California; U.S. Immigration Status $=$ U.S. citizen

Note: “---" variable included in the model, "-" variable excluded from the model.

Significance at the * $p<0.10 ; \dagger p<0.05$; and $\ddagger p<0.01$ levels.

Source: Authors' calculation from the National Agricultural Workers Survey, 1989-2009. 
business ownership by $27.4 \%$ over non-migrants. Longevity as a farmworker in the U.S. also increases the odds of business ownership by $1.2 \%$ per additional year worked. The odds of owning a business were higher for those interviewed in the East, Southeast, Midwest, and Northwest as compared to California. Lastly, other work authorization increases the odds of business ownership $260 \%$ over U.S. citizen farmworkers.

\section{Results of Model 3}

Model 3 includes all identified variables; however, the amount of missing data omits $44.4 \%$ of the respondents included in Model 1. Hence only very tentative insights may be drawn due to the reduced sample size for new variables regarding English language ability and income under consideration. English language ability increases the odds of business ownership, whereby spoken English (a little, and somewhat) and good English reading ability are the significant findings. Because of the amount of missing data, income plays no consequential role in the results.

\section{Model Agreement}

Of particular importance is the convergence and consistency of the models. Combining the models, a summary result for business ownership vis-à-vis agricultural workers indicates that (1) business owners are more likely to be male; (2) additional years of work experience as a U.S. farmworker increase the odds of business ownership; (3) the odds of business ownership increase for married farmworkers over those who are not married; (4) the more education a farmworker has achieved, the greater the odds that the farmworker will also be a business owner (with the odds increasing at every step up the educational ladder); (5) English language ability increases the odds of business ownership; and (6) farmworkers in the East, Southeast, Midwest, and Northwest are more likely to engage in business ownership than farmworkers in California and the Southwest.

\footnotetext{
15 The primary source of income for business owners is farm work. Business owners who own a business in their home country work on average 19.6 weeks per year as a farmworker and 6.7 weeks as a non-farmworker, and spend another 4.4
}

\section{Examination of Business Owners by Business Location (U.S. or Home Country)}

In this section we examine the 500 business owners by location of their business. By business location, $69.4 \%$ of farmworker businesses are located in the U.S. and the remaining $30.6 \%$ are situated in the respondent's home country (no native-born U.S. citizen farmworker owned a business outside the U.S. in the NAWS data set). Table 3 reports the descriptive statistics for business owners divided between business owners with a location in the U.S. and those who own a business located in their home country (outside the U.S.), an overwhelmingly proportion of which are in Mexico (91.5\%). For ease of discussion, "business in the U.S." refers to a U.S. farmworker and business owner with a business in the U.S., while "business in their home country" (or outside the U.S.) refers to a U.S. farmworker and business owner with a business in their country of origin.

Respondents who own a business in the U.S. are generally split between men $(57.2 \%)$ and women $(42.8 \%)$, and most are middle-aged (mean age is 41.0 years) and married $(75.4 \%)$. Business owners in the U.S. mostly hail from the U.S. $(72.4 \%)$ and in regards to nativity are primarily U.S. citizens $(76.6 \%)$; of note, only about one-third identify as Hispanic, though one-quarter originate from Mexico and Central America. Nearly twothirds of U.S. business owners possess a high school education or higher and are not very likely to migrate or cross international boundaries while working as a U.S. farmworker (4.3\%). More than eight in ten U.S. business owners have the facility to communicate in English, and a majority $(71.5 \%)$ is most comfortable conversing in English. U.S. business owners have worked on average 16 years as a farmworker in the U.S. and are overrepresented in the Midwest (42.9\%) and underrepresented in California (11.0\%) as compared to farmworkers more generally. Lastly, personal and family incomes are 1.5 and 1.8 times greater than average farmworker incomes, respectively. ${ }^{15}$

weeks on average not working. Business owners who own a business in the U.S. work on average 28.9 weeks per year as a farmworker and 11.8 weeks as a non-farmworker, and spend another 11.3 weeks on average not working. 
Respondents with a business in their home country are primarily male (81.6\%), unauthorized to be in the U.S. $(59.9 \%)$, Hispanic (94.7\%), Spanish speakers $(92.6 \%)$, and are relatively young (mean age is 33.0 years). Home country business owners also tend to be married (61.4\%), and own their business principally in Mexico (91.5\%). Few $(16.3 \%)$ who own businesses in the home country possess educations beyond middle school or have the ability to communicate in English (13.1\%), and most are on the move within the U.S. (75.5\% are migrant farmworkers) and across the border to work as farmworkers $(60.1 \%$ are international shuttlers).

Home country business owners have worked on U.S. farms for a relatively short period of time (5 years on average) and are overrepresented in the East $(22.5 \%)$ and Southeast $(34.6 \%)$ and underrepresented in
Table 3. U.S. Farmworker Business Ownership Demographics at Time of Survey (1989-2009) by Country Location

\begin{tabular}{|c|c|c|}
\hline Variable & In U.S. & In Home Country \\
\hline \multicolumn{3}{|l|}{ Gender (\%) } \\
\hline Male & 57.2 & 81.6 \\
\hline Female & 42.8 & 18.4 \\
\hline Mean Age (std. dev.) & $41.0(12.2)$ & $33.0(10.7)$ \\
\hline \multicolumn{3}{|l|}{ Civil Status (\%) } \\
\hline Single & 19.7 & 38.6 \\
\hline Married/Living Together & 75.4 & 61.4 \\
\hline Divorced/Separated/Widowed & 4.9 & 0.0 \\
\hline \multicolumn{3}{|l|}{ Birthplace (\%) } \\
\hline U.S. & 72.4 & 0.0 \\
\hline Puerto Rico & 1.4 & 0.0 \\
\hline Mexico & 23.9 & 91.5 \\
\hline Central America & 1.1 & 5.9 \\
\hline Other & 1.1 & 2.6 \\
\hline \multicolumn{3}{|l|}{ Education-Highest Grade Level Completed (\%) } \\
\hline None & 1.4 & 2.0 \\
\hline Elementary (1-6 grades) & 10.1 & 62.7 \\
\hline Middle School (7-9 grades) & 9.5 & 19.0 \\
\hline Some High School (10-11 grades) & 14.5 & 8.5 \\
\hline High School (12 grades) & 36.7 & 5.2 \\
\hline Some College and Beyond & 27.7 & 2.6 \\
\hline International Shuttler-Yes (\%) & 4.3 & 60.1 \\
\hline Migrant Farmworker-Yes (\%) & 14.7 & 75.5 \\
\hline Hispanic-Yes (\%) & 34.6 & 94.7 \\
\hline \multicolumn{3}{|l|}{ Speak English (\%) } \\
\hline Not at all & 7.7 & 44.3 \\
\hline A little & 12.6 & 42.7 \\
\hline Somewhat & 9.3 & 3.1 \\
\hline Well & 70.4 & 9.9 \\
\hline \multicolumn{3}{|l|}{ Read English (\%) } \\
\hline Not at all & 9.5 & 66.2 \\
\hline A little & 9.5 & 20.8 \\
\hline Somewhat & 3.6 & 3.1 \\
\hline Well & 77.5 & 10.0 \\
\hline \multicolumn{3}{|l|}{ Language Most Comfortable Conversing In... (\%) } \\
\hline English & 71.5 & 0.0 \\
\hline Spanish & 26.7 & 92.6 \\
\hline Other & 1.7 & 7.4 \\
\hline Mean Years Worked on the Farm in the U.S. (std. dev.) & $16.1(12.6)$ & $5.4(5.2)$ \\
\hline \multicolumn{3}{|l|}{ Interview Region (\%) } \\
\hline East & 20.7 & 25.5 \\
\hline Southeast & 9.5 & 34.6 \\
\hline Midwest & 42.9 & 22.2 \\
\hline Southwest & 2.3 & 2.6 \\
\hline Northwest & 13.5 & 5.9 \\
\hline California & 11.0 & 9.2 \\
\hline \multicolumn{3}{|l|}{ Adjusted Income (in 2009 U.S. dollars) } \\
\hline Mean Personal Income (std. dev.) & $20,323(17,184)$ & $13,142(16,481)$ \\
\hline Mean Family Income (std. dev.) & $33,252(21,026)$ & $14,686(17,051)$ \\
\hline \multicolumn{3}{|l|}{ U.S. Immigration Status (\%) } \\
\hline U.S. Citizen & 76.6 & 0.0 \\
\hline U.S. Green Card & 14.7 & 6.8 \\
\hline Other Work Authorization & 1.2 & 33.3 \\
\hline Unauthorized & 7.5 & 59.9 \\
\hline Weighted $N$ & 347 & 153 \\
\hline
\end{tabular}

Italics=Statistically different at the .001 level. There may be some errors due to rounding.

Source: Authors' calculation from the National Agricultural Workers Survey, 1989-2009. 
Table 4. Logistic Regression Results (Odds Ratios) for Business Ownership by Country Location (Own business in U.S.=1)

\begin{tabular}{|c|c|c|c|}
\hline Variable & $\begin{array}{c}\text { Model } 1 \\
\operatorname{Exp}(\beta)\end{array}$ & $\begin{array}{c}\text { Model } 2 \\
\operatorname{Exp}(\beta)\end{array}$ & $\begin{array}{c}\text { Model } 3 \\
\operatorname{Exp}(\beta)\end{array}$ \\
\hline Gender $(\text { Male }=1)^{a}$ & 2.320 & 3.023 & .324 \\
\hline Age (Years) & $1.049 \dagger$ & $.791 \ddagger$ & $.778 \ddagger$ \\
\hline Civil Status & -- & --- & --- \\
\hline Married/Living Together & $2.446 *$ & 1.733 & .552 \\
\hline Separated/Divorced/Widowed & $1.331+\mathrm{E} 8$ & $5.417 \mathrm{E}+9$ & $6.804 \mathrm{E}+12$ \\
\hline Birthplace & $--{ }^{*}$ & --- & --- \\
\hline Mexico & .000 & $7.908 \mathrm{E}+9$ & $1.371 \mathrm{E}+6$ \\
\hline Central America & .000 & 1.037E+11 & $4.709 E+6$ \\
\hline Other & .000 & $2.005 E+3$ & .798 \\
\hline Education & $--\dagger$ & $--\dagger$ & --- \\
\hline Elementary (1-6) & .443 & .188 & .161 \\
\hline Middle School (7-9) & .762 & 1.512 & .465 \\
\hline Some High School (10-11) & .631 & 2.005 & .243 \\
\hline High School (12 grades) & 1.459 & $.003 *$ & .002 \\
\hline Some College and Beyond & $37.869+$ & 146.145 & 90.835 \\
\hline International Shuttler (Yes=1) & $.167 \ddagger$ & .498 & .217 \\
\hline Migrant Farmworker $($ Yes $=1)$ & - & $.103^{*}$ & $.022 \dagger$ \\
\hline Hispanic $(Y e s=1)$ & - & $6.247 E+6$ & $1.162 \mathrm{E}+2$ \\
\hline Speak English & - & - & -- \\
\hline A little & - & - & .176 \\
\hline Somewhat & - & - & 6.741 \\
\hline Well & - & - & 88.569 \\
\hline Read English & - & - & -- \\
\hline A little & - & - & 1.394 \\
\hline Somewhat & - & - & .105 \\
\hline Well & - & - & .000 \\
\hline Language Most Comfortable Conversing In... & - & $--\ddagger$ & --- \\
\hline Spanish & - & .000 & .000 \\
\hline Other & - & .000 & .000 \\
\hline Years Worked on the Farm in the U.S. & - & $1.350 \dagger$ & $1.407 \ddagger$ \\
\hline Interview Region & $--\ddagger$ & $--\dagger$ & $--\ddagger$ \\
\hline East & $.116 \ddagger$ & .201 & .177 \\
\hline Southeast & $.111 \ddagger$ & $.032 \dagger$ & $.020 \dagger$ \\
\hline Midwest & $.220 \ddagger$ & 7.497 & $133.197 *$ \\
\hline Southwest & .263 & .260 & .142 \\
\hline Northwest & .803 & 2.175 & 1.942 \\
\hline Personal Income & - & - & $1.000 *$ \\
\hline Family Income & - & - & $1.000 \dagger$ \\
\hline U.S. Immigration Status & - & $---*$ & $--\ddagger$ \\
\hline U.S. Green Card & - & .000 & .000 \\
\hline Other Work Authorization & - & .000 & .000 \\
\hline Unauthorized & - & .000 & .000 \\
\hline $\begin{array}{l}\text { Weighted N: All [Own/Buying a Business in } \\
\text { U.S. Home Country] }\end{array}$ & 499 [346|153] & 439 [309|130] & $277[193 \mid 84]$ \\
\hline Model Diagnostics -2LL & 193.158 & 71.769 & 49.947 \\
\hline$x^{2}$ & 420.641‡ & 461.727‡ & $289.960 \ddagger$ \\
\hline Cox \& Snell R2 & .570 & .650 & .649 \\
\hline Nagelkerke $\mathrm{R}^{2}$ & .805 & .925 & .918 \\
\hline
\end{tabular}

a Reference categories: Gender=Male, Civil Status=Single; Birthplace=Born in U.S./Puerto Rico; Education= None; International Shuttler=Yes; Hispanic=Yes; Speak English=Not at all; Read English=Not at all; Language Most Comfortable Conversing In=English; Interview Region=California; U.S. Immigration Status=U.S. citizen. Significant at the * $p<0.10 ; \dagger p<0.05$; and $\ddagger p<0.01$ levels.

Note: “---" variable included in the model, "-" variable excluded from the model.

Source: Authors' calculation from the National Agricultural Workers Survey, 1989-2009.

${ }^{16}$ Logistic regression diagnostics across all three models are acceptable.
California $(9.2 \%)$ as compared to farmworkers generally. Home country business owners earn incomes (mean annual personal income is US $\$ 13,142$ ) similar to U.S. farmworkers at large.

Similar to the analysis reported in Table 2 and following the method employed in Table 2 , we utilized a logistic regression ${ }^{16}$ to differentiate U.S. business owners (=1) from home country business owners (see Table 4). In the first model comprising $99.8 \%$ of all business owners in the NAWS, age, civil status, education, international shuttling, and interview region were significant in the analysis. Each additional year of life increased the odds of U.S. business ownership by 4.9\%. Marriage increased the odds by $145 \%$ for U.S. business ownership over their nonmarried home country owned business counterparts. Education is a key differentiator, 
with the odds of the college-educated owning a business in the U.S. 36.9 times greater than those owning a business in their home country with no formal education. Shuttling across the border to engage in farm work also is an important partition for location of business ownership, where shuttling reduces the odds by $83.3 \%$ of owning a U.S.-based business in reference to owning a business situated outside the U.S. Lastly, the odds of owning a business in the U.S. among respondents in the East, Southeast, and Midwest were much lower, $88.4 \%$, $88.9 \%$, and $78.0 \%$, respectively, as compared to those business owners interviewed in California.

Model 2 permits more variables to be included in the analysis, although the sample of business owners is reduced by $12.2 \%$ due to missing data. Unlike model 1, an additional year of age reduces the odds of owning a U.S. business by $2.1 \%$ per year. Education, at least for the specific segment having completed high school as compared to those with no education, also reduces the odds of U.S. business ownership by $99.7 \%$. Work as a migrant farmworker also decreases the odds of U.S. business ownership by $89.7 \%$. Yet longer service as a farmworker increases the odds of U.S. business ownership by $3.5 \%$ per year worked as a U.S. farmworker. Lastly, the odds of U.S. business ownership for respondents interviewed in the Southeast are reduced $96.8 \%$ as compared to respondents interviewed in California.

Model 3, comprising all the independent variables, includes only $55.4 \%$ of the business owner sample, so these results are tentative based on the reduced sample size. As in model 2, age and migrant work status are inversely related to the odds of U.S. business ownership-that is, each additional year reduces the odds of U.S. business ownership by $22.2 \%$, and work as a migrant farmworker reduces the odds of U.S. business ownership by $97.8 \%$ in relation to non-migrant farmworkers. Years worked on a U.S. farm increase the odds of U.S. business ownership by $40.7 \%$ per additional year worked. And while income is positively associated with the increased odds of U.S. business ownership, the effect is negligible. As compared to those interviewed in California, respondents interviewed in the Midwest increase their odds of U.S. business ownership 132.2 times, whereas those interviewed in the Southeast find their odds of U.S. business ownership reduced by $98.0 \%$.

In summary, the multivariate findings for business ownership in the U.S. include: (1) mixed results for age across models, although results for the entire sample suggest that maturity is associated with U.S. business ownership; (2) college education enhances the odds of U.S. business ownership; (3) respondents on the move (shuttling and migrant work) have reduced odds of owning a business in the U.S.; and (4) mixed results by interview region provide little help in distinguishing regional business ownership trends.

\section{Discussion}

While the NAWS does not identify business owners operating their enterprises as formal or informal concerns, citizenship and work authorization aligns with the country where the business is located. As such, most business owners can choose to operate a formal business, and most likely do so. However, previous research has uncovered that work-authorized residents on either side of the South Texas-Northern Mexico border engage in informal entrepreneurship to maximize business opportunities (Pisani \& Yoskowitz, 2006;

Richardson \& Pisani, 2012). The remainder of this section is partitioned into two segments: the first discusses the results for business ownership vis-àvis non-business ownership for agricultural workers, and the second discusses the results for business ownership in the U.S. versus home country among agricultural workers.

\section{Business Ownership vis-à-vis Non-business Ownership}

The overall count of business owners is heavier early in the survey sample years. This may be the result of regularization of immigration status for many who came before 1986 and benefitted from the passage of IRCA as well as stricter border enforcement (Gentsch \& Massey, 2011) in subsequent years, making the cost of crossing the border more expensive for those who shuttle across the international border and in turn limiting funds and savings for other purposes such as business ownership. Hazán (2014) also found that the proportion of returning migrants to Mexico who engage in 
self-employment has fallen precipitously since 2005, and even fewer employ others. ${ }^{17}$ Additionally, stronger connections to the U.S. spur business ownership, particularly with regard to U.S. nativity, English language ability, and length of service as a U.S. farmworker. Those less likely to engage in migrant farm work have increased odds of owning a business; unless the business itself is itinerant, this follows a more established pattern of business development in a fixed location. Relationship stability and partnership created through marriage, as in stability in location, may also foster an environment conducive to business formation. There is a robust association between progressively higher levels of education and business ownership, indicating that increased investment in human capital through education translates into opportunity recognition in the form of business ownership. Women possess higher levels of education relative to men for both business owners and farmworkers, yet overall the odds are greater that men are business owners, perhaps due to household resource control. Lastly, business owners outside California are able to seize upon business opportunities in larger proportions, perhaps the result of co-ethnic market saturation in California. ${ }^{18}$

\section{Business Ownership in the U.S. Versus Home Country}

The higher percentage of business ownership in the U.S. reflects a proportionally higher incidence of U.S. birth origin as well as permanency of U.S. residence. U.S. business owners may more easily navigate the U.S. business environment because of their comfort level operating in English, educational attainment, and geographic and family stability. Women own nearly as many U.S. businesses as men. Surprisingly, only one-third of U.S. business owners self-identify ethnicity as Hispanic, whereas nearly $80 \%$ self-identify racially as white,

\footnotetext{
${ }^{17}$ In 2005, 26.4\% of returning Mexican migrants were selfemployed in Mexico upon their return. This proportion dropped to $14.9 \%$ by 2012 , and only $5 \%$ of returning Mexican migrants employed others in 2012 (Hazán, 2014).

18 The 2012 Survey of Business Owners conducted by the U.S. Census Bureau tabulates over 818,000 Hispanic-owned businesses in California, accounting for $25 \%$ of all Hispanicowned businesses in the U.S.
}

$14 \%$ as other, and $4 \%$ as black. The rate of Hispanic business owners and agricultural workers, like their Hispanic business owner counterparts in the general U.S. workplace, fall below the U.S. average. Dávila and Mora (2013) have argued that institutional and demographic constraints, such as credit rationing, discriminatory borrowing terms, and cultural reluctance to seek debt financing, may lead to this outcome.

For those business owners with a business outside the U.S., nearly all of these businesses are located in Mexico. These business owners correspondingly possess strong natal and cultural (e.g., language, ethnicity) ties to Mexico and strong migratory links to Mexico and U.S. field crops. Within this group, the ability to conduct business at home is not limited by age, education, or time spent away in the U.S. While the literature is mixed as far as remittances and agricultural investment (Böhme, 2014), it appears that earnings from U.S. farm work may facilitate business formation for some (upwards of $20 \%$ devoted to small business investment ranging from US $\$ 2,700$ to US $\$ 5,400$ in one study of returning Mexican migrants [Hazán, 2014], but only $8 \%$ in another study [Cohen \& Rodriguez, 2004]), but not for many cross-border migrant farmworkers in their home country. ${ }^{19}$

\section{Two Case Studies Exhibiting the Pathway to Business Formation in the U.S.}

While the NAWS does not provide additional information as to the type of business owned by farmworkers, we introduce two anecdotal case studies to suggest possible pathways agricultural workers may demonstrate in their entrepreneurial endeavors. ${ }^{20}$ Both of these illustrate the cases of Mexican migrants who came to the U.S. as undocumented agricultural workers and over time leveraged the knowledge of their agricultural experiences into business ownership.

\footnotetext{
${ }^{19}$ The literature is clear with regard to remittances augmenting consumption in the receiving communities.

20 These two cases are embedded in the public record (see Quinones, 2007, chapter 2, and Berryessa Gap website [http://www.berryessagap.com]) and the subjects are known personally by the first author, who is a native of Winters, California.
} 
Tucked into the trunk of a car, Andrés Bermúdez and his pregnant wife Irma crossed the U.S.-Mexico border clandestinely in 1973 from Tijuana to California. Their U.S. journey began as undocumented migrants looking to improve their lot in life by finding work in the U.S. Andrés came from an impoverished rural hamlet in Jerez, Zacatecas, Mexico. There his family owned a few cows, sold cheese in the local marketplace, and barely had enough resources to survive. But not all survived; as a child Andrés watched his baby sister succumb to the flu for lack of adequate medical treatment.

But 1973 was not Andrés' first entry into the U.S.; he had successfully found agricultural employment in the Sacramento Valley of northern California in 1970 at age 20. Andrés was simply returning to work after securing transit for his Mexican wife. Andrés, like tens of thousands of his compatriots, flocked to small agricultural towns across California and the U.S. to provide field and agricultural labor in a labor market increasingly dominated by Mexican foreign nationals as the native-born retreated into less arduous employment. What sets Andrés apart from the multitude of agricultural workers is his work trajectory from field worker to business owner, a process that took more than 20 years.

Not unlike many of the agricultural worker/ U.S. business owners in the NAWS sample, where $69.4 \%$ had purchased or were in the process of buying a plot of land in the U.S. at the time of the survey, Andrés too was able to save up and buy his own plot of land while he transitioned from fulltime agricultural worker to full-time business owner. Throughout this process, his work on the farm morphed from farmworker, to foreman, driver, and labor contractor. Along the way, Andrés benefitted from the Immigration Reform and Control Act of 1986, through which he was able to regularize his immigration status first as a U.S. green card holder and then as a U.S. citizen.

The region of California (Yolo County) where Andrés worked was tomato country, though many other crops and fruits are also grown in the area. But it was tomatoes that eventually transformed Andrés' life. He invented a machine that facilitated the transplant of tomato seedlings from greenhouse to field. This invention allowed Andrés to slowly transition from farmworker to business owner; because of this invention, he eventually became a grower and relatively wealthy farmer. For many Mexican migrants, Andrés Bermúdez became el rey de tomate (the tomato king) and a flamboyant "rags to riches" role model.

Andrés' success was noticed, not only in his adopted hometown of Winters, but also in his natal hometown of Jerez. Even the governor of Zacatecas came to Winters in 2000 to fête Andrés. Election laws changed in Mexico to allow expatriates the opportunity not only to vote, but to run for political office. Andrés Bermúdez became the first immigrant elected mayor in Jerez, Zacatecas, in 2001, was re-elected in 2004, and eventually served as a Mexican congressman with the Partido Acción Nacional (PAN). Andrés met an untimely death in 2009 at the age of 58 from stomach cancer.

As a young man, Santiago Moreno left his native Jalisco, Mexico, in the late 1970s and shortly thereafter arrived undocumented in Winters, California. Santiago followed a familiar route like many in his community in Jalisco, traveling clandestinely across the border to find agricultural work in California. Santiago not only found agricultural employment, but also supplemented his agricultural earnings with a second informal job mowing lawns, which allowed him to reside fulltime and begin a family in Winters.

Santiago had a penchant and "green thumb" for trees, plants, and vines, and his botanical acumen was discovered early on by one of his first employers. With his employer, Santiago was identified to help and partner in the development of a budding rootstock nursery for grapevines in the latter half of the 1980s. Santiago was especially adept at growing rootstock in a region known for producing fine wines. (Winters is located on the east side of the California Coastal range about 30 miles [48 km] from Napa in Yolo County.) Nevertheless, the rootstock endeavor began as a secondary source of income while Santiago worked his way up in his primary occupation, moving from agricultural laborer to field manager and then operational supervisor of a small prune dehydrator.

The passage of IRCA regularized Santiago's 
immigration status at a propitious moment in time (the late 1980s) as Santiago held part-interest in the rootstock nursery. With regularization of status, Santiago became a full legal business partner with his agricultural employer by the early 1990s in the rootstock nursery. Throughout the 1990s Santiago also maintained his position as a field supervisor and prune dehydrator manager.

The continuing boom in California wines transformed and expanded Santiago's agricultural business holdings in the new millennium to winemaker, as a part owner of Berryessa Gap Vineyards (in 2004). Santiago Moreno, while less flamboyant than Andrés Bermúdez, nevertheless still leads by example as he continues his work in the fields and in the winery providing grapes for Berryessa Gap Winery and others in and around Winters. Interestingly, the farm in which Andrés worked during his early, undocumented years in Winters is now part of the production facilities for Berryessa Gap.

Both Andrés Bermúdez and Santiago Moreno arrived in Winters, California, in the 1970s as landless, undocumented immigrants from Mexico. Within two decades, both had become entrepreneurs and normalized their immigration status to U.S. citizen through the procedures offered by IRCA. The business ownership trajectories of these two agricultural laborers are representative of the empirical analysis presented above of U.S. business ownership where male, middle-aged, married, experienced, and settled agricultural workers in California are more likely to become business owners.

Agricultural work and ingenuity provided a pathway toward entrepreneurship and business ownership. No doubt both Andrés Bermúdez and Santiago Moreno are exceptional examples of agricultural workers and entrepreneurs who have leveraged their agricultural experiences into business ownership. With over 1 million agricultural workers in the U.S., there are approximately 10,000 or more stories like that of Andrés Bermúdez and Santiago Moreno.

\footnotetext{
21 The proposed DREAM Act is an acronym for Development, Relief, and Education of Alien Minors, which in part would allow for the regularization of immigration status for
}

\section{Conclusion}

This paper has explored the determinants of membership in the exceptional one percent of U.S. farmworkers who are also business owners by analyzing the NAWS for the years 1989 to 2009. The exceptional one percent own businesses in the U.S. or their home country (that is, Mexico for all intents and purposes). Implications for business growth and entrepreneurship abound where even in the most trying of occupations - agricultural work- entrepreneurial outcomes are possible for agricultural workers as chronicled in the case studies of Andrés Bermúdez and Santiago Moreno and described in the empirical analysis above. Fostering business growth from this group, and like groups, requires an adjustment of public policy outlook where entrepreneurship is seen as an engine of economic growth and community development, the genesis of which may come from unexpected places. Holcomb (2008) suggests, then, a shift in emphasis "toward the creation of an environment within which opportunities for entrepreneurial activity are created, and successful entrepreneurship is rewarded" (p. 71).

Our analysis suggests that nurturing business growth from this group of agricultural workers within the U.S. requires investment in human capital, most notably education and English language acquisition, as well as the regularization of immigration status that permits stability and institutional access for men and women. Education has the largest effect on improving the odds of agricultural workers becoming business owners, and collegelevel education more so. Not only is early childhood education and Migrant and Seasonal Head Start important, our research also illustrates the potential positive externalities of such policy initiatives as in-state tuition initiatives for undocumented students currently available in 18 states (National Conference of State Legislatures [NCSL], 2015) and the adoption of the federal DREAM Act. ${ }^{21}$ Continued support of English as a second language and use of the existing kindergartenthrough-twelfth-grade public education

undocumented persons brought into the U.S. before the age of 16 if they attend an institution of higher education for two years or serve honorably in the U.S. military for two years. A 
infrastructure will assist in English language acquisition. Lastly, comprehensive immigration reform, regularizing the status of the nearly 12 million undocumented in the U.S., 8 million of whom work (Passel \& Cohn, 2014) with perhaps as many as 450,000 in any given year working in agriculture, would liberalize institutional barriers to business ownership and allow for a more public process of co-ethnics assisting one another without fear of government retribution. Auxiliary training in basic business skills and regulatory compliance may be funneled through existing channels such as the Small Business Administration with sensitivity to the need to offer services in Spanish.

Mexico, on the other hand, should continue its efforts to transform the flow of remittances from consumption into productive investments (both private and public) and to pursue institutional reforms in the ease of doing business. ${ }^{22}$ One innovative Mexican program is the tres por uno (three for one) match provided by the Secretariat for Social Development (Secretaría de Desarollo Social, or SEDESOL). For every one peso sent to Mexico, the Mexican government will match 3 pesos to the donation in a specific location (SEDESOL, 2015). In essence, this triples the impact of remittances, primarily for local infrastructure projects (e.g., roads, potable water). Another way to further enhance economic growth would be to redirect the flow of some of these remittances and matches to the entrepreneurship ecosystem, such as new venture funds for start-up businesses, incubators, and accelerators. Orrenius, Zavodny, Cañas, and Coronado (2010) suggest that much of the remittance flow to Mexico enhances consumption and reduces unemployment and income inequality (because of outflow migration from poorer areas, which also allows for those left behind to leave the workforce due to incoming income flows). The World Bank comprehensively tracks the ease of doing business by country. Mexico ranks $38^{\text {th }}$ overall, first in Latin America but far behind the U.S., which places $7^{\text {th }}$ in the ease of doing business (World Bank, 2015). Additionally, the institutional

state version of the DREAM Act is available in a handful of states, including California (Clark-Ibáñez, 2015).

22 The World Bank has been reporting the "ease of doing environment permits widespread informality, where nearly $60 \%$ of Mexicans work in the informal sector (International Labour Office, 2014). In both cases, Mexico is working toward erasing regulatory barriers in the formal economy and welcoming the informal sector within the general economy.

A limitation of using the NAWS as a marker of business ownership is the lack of follow-up questions concerning the business enterprise, such as ownership shares, specific locale, and business formality. However, further qualitative research may complement the NAWS in providing more extensive case-study accounts of business ownership in the U.S. and home country.

\section{References}

Böhme, M. H. (2014). Does migration raise agricultural investment? An empirical analysis for rural Mexico. Agricultural Economics. Advance online publication. http://dx.doi.org/10.1111/agec.12136

Borjas, G. J., \& Katz, L. F. (2007). The evolution of the Mexican-born workforce in the United States. In G. J. Borjas (Ed.), Mexican Immigration to the United States (pp. 13-55). Chicago: The University of Chicago Press.

Calo, B. V. (1995). Chicano entrepreneurs in rural California: An empirical analysis. (Unpublished doctoral dissertation). University of California, Davis.

Clark-Ibáñez, M. (2015). Undocumented Latino youth: Navigating their worlds. Boulder, Colorado: Lynne Reinner Publishers.

Cohen, J. H. \& Rodriguez, L. (2004). Remittance outcomes in rural Oaxaca, Mexico: Challenges, options, and opportunities for migrant households (Working Paper No. 102). San Diego: Center for Comparative Immigration Studies, University of California. Retrieved from https://www.researchgate.net/ publication/227507132 Remittance outcomes in rural Oaxaca Mexico Challenges options and opportunities for migrant households

Dávila, A. \& Mora, M. T. (2013). Hispanic entrepreneurs in the 2000s: An economic profile and policy implications. Stanford, California: Stanford University Press.

business" by country for many years. See the index at http://data.worldbank.org/indicator/IC.BUS.EASE.XQ 
Gentsch, K, \& Massey, D. S. (2011). Labor market outcomes for legal Mexican immigrants under the new regime of immigration enforcement. Social Science Quarterly, 92(3), 875-893. http://dx.doi.org/ 10.1111/j.1540-6237.2011.00795.x

Hazán, M. (2014). Understanding return migration to Mexico: Towards a comprehensive policy for the reintegration of returning migrants (Working Paper No. 189). San Diego, California: Center for Comparative Immigration Studies, University of California, San Diego.

Hoerster, K. D., Beddawi, S., Peddecord, K. M., \& Ayala, G. X. (2010). Healthcare use among California farmworkers: Predisposing and enabling factors. Journal of Immigrant and Minority Health, 12(4), 506-512. http://dx.doi.org/10.1007/s10903-0099305-0

Holcomb, R. G. (2008). Entrepreneurship and economic growth. In B. Powell (Ed.), Making poor nations rich: Entrepreneurship and the process of economic development (pp. 54-78). Stanford, California: Stanford University Press.

International Labour Office. (2014). Informal employment in Mexico: Current situation, policies and challenges: Notes on formalization. Retrieved on October 29, 2015, from http://www.ilo.org/wcmsp5/groups/ public/---americas/---ro-lima/documents/ publication/wcms_245889.pdf

Isé, S \& Perloff, J. M. (1995). Legal status and earnings of agricultural workers. American Journal of Agricultural Economics, 77(2), 375-386. http://dx.doi.org/10.2307/1243547

Kandel, W. A. \& Donato, K. M. (2009). Does unauthorized status reduce exposure to pesticides? Evidence from the National Agricultural Workers Survey. Work and Occupations, 36(4), 367-399. http://dx.doi.org/10.1177/0730888409347599

Kandilov, A. M. G., \& Kandilov, I. T. (2010), The effect of legalization on wages and health insurance: Evidence from the National Agricultural Workers Survey. Applied Economic Perspectives and Policy, 32(4), 604-623. http://dx.doi.org/10.1093/aepp/ppq022

Kirzner, I. M. (1973). Competition and entrepreneurship. Chicago: University of Chicago Press.

Light, I. (2005). The ethnic economy. In N. J. Smesler \& R. Swedberg (Eds.), The handbook of economic sociology (2nd Ed.) (pp. 650-677). New York: Russell Sage Foundation.
Lofstrom, M. \& Bates, T. (2009). Latina entrepreneurship. Small Business Economics, 33, 427-439. http://dx.doi.org/10.1007/s11187-009-9203-9

Lopez, M. H. (2013, October 28). Hispanic or Latino? Many don't care, except in Texas [Blog post]. Retrieved from http://www.pewresearch.org/facttank/2013/10/28/in-texas-its-hispanic-por-favor/

Malkin, V. (2004). 'We go to get ahead': Gender and status in two Mexican migrant communities. Latin American Perspectives, 31(5), 75-99. http://dx.doi.org/10.1177/0094582X04268402

National Conference of State Legislatures [NCSL]. (2015, October 29). Undocumented student tuition: Overview. Retrieved from http://www.ncsl.org/ research/education/undocumented-student-tuitionoverview.aspx

Orrenius, P. M., Zavodny, M., Cañas, J., \& Coronado, R. (2010). Do remittances boost economic development? Evidence from Mexican states (Working Paper No. 1007). Dallas, Texas: Federal Reserve Bank of Dallas. Retrieved from https://www.dallasfed.org/ assets/documents/research/papers/2010/wp1007. pdf

Passel, J. S. \& Cohn, D. (2014). Unauthorized immigrant totals rise in 7 states, fall in 14: Decline in those from Mexico fuels most state decreases. Washington, D.C.: Pew Research Center Hispanic Trends Project. Retrieved from http:/ /www.pewhispanic.org/ files/2014/11/2014-11-18_unauthorizedimmigration.pdf

Pena, A. A. (2010). Poverty, legal status, and pay basis: The case of U.S. agriculture. Industrial Relations, 49(3), 429-456. http://dx.doi.org/10.1111/j.1468232X.2010.00608.x

Pena, A. A. (2012). Undocumented immigration and the business of farm labor contracting in the USA. American Journal of Business, 27(1), 10-26. http://dx.doi.org/10.1108/19355181211217616

Pena, A. A. (2014). Undocumented immigrants and the welfare state: The case of regional migration and U.S. agricultural labor. Journal of Regional Science, 54(1), 96-113. http://dx.doi.org/10.1111/jors.12049

Pisani, M. J. (2012). Latino informal immigrant entrepreneurs in South Texas: Opportunities and challenges for unauthorized new venture creation and persistence. American Journal of Business, 27(1), 27-39. http://dx.doi.org/10.1108/19355181211217625 
Pisani, M. J., \& Yoskowitz, D. W. (2006). Opportunity knocks: Entrepreneurship, informality and home gardening in South Texas. Journal of Borderlands Studies, 21(2), 59-76. http://dx.doi.org/10.1080/08865655.2006.9695660

Portes, A \& Haller, W. (2005). The informal economy. In N. J. Smesler \& R. Swedberg (Eds.), The handbook of economic sociology (2nd Ed.) (pp. 403-425). New York: Russell Sage Foundation.

Quinones, S. (2007). Antonio's gun and Delfino's dream: True tales of Mexican migration. Albuquerque: University of New Mexico Press.

Richardson, C. Pisani, M. J. (2012). The informal and underground economy of the South Texas border. Austin: University of Texas Press.

Rochín, R. I. (2013). Rural Latinos: An assessment of evolving conditions. In M. T. Mora \& A. Dávila (Eds.), The economic status of the Hispanic population: Selected Essays (pp. 81-93). Charlotte, North Carolina: Information Age Publishing.

Rochín, R. I., Saenz, R., Hampton, S., \& Calo, B. (1998). Colonias and Chicano/ a entrepreneurs in rural California (Research Report No. 16). East Lansing: Julian Samora Research Institute, Michigan State University. Retrieved from http://www.jsri. msu.edu/upload/research-reports/rr16.pdf

Schumpeter, J. A. (1912/1934/1983). The theory of economic development: An inquiry into profits, capital, credit, interest, and the business cycle (R. Opie, Trans.). New Brunswick, New Jersey: Transaction Publishers.

Secretariat for Social Development Secretría De Desarollo Social [SEDESOL]. (2015). 3X1 para migrantes [3x1 for migrants]. Retrieved October 29, 2015, from http://www.gob.mx/tramites/ficha/ solicitud-de-apoyos-para-proyectos-al-programa3x1-para-migrantes/SEDESOL317

Shane, S., \& Venkataraman, S. (2000). The promise of entrepreneurship as a field of research. Academy of Management Review, 25(1), 217-226. http://dx.doi.org/10.5465/AMR.2000.2791611
Shinnar, R. S., \& Young, C. A. (2008). Hispanic immigrant entrepreneurs in the Las Vegas metropolitan area: Motivations for entry into and outcomes of self-employment. Journal of Small Business Management, 46(2), 242-262. http://dx.doi.org/10.1111/j.1540627X.2008.00242.x

Striffler, S. (2007). Neither here nor there: Mexican immigrant workers and the search for home.

American Ethnologist, 34(4), 674-688. http://dx.doi.org/10.1525/ae.2007.34.4.674

Tienda, M. \& Raijman, R. (2004). Promoting Hispanic immigrant entrepreneurship in Chicago. Journal of Developmental Entrepreneurship, 9(1), 1-21.

U.S. Census Bureau. (2011, March). Overview of race and Hispanic origin: 2010 [2010 Census Brief]. Retrieved from http://www.census.gov/prod/cen2010/ briefs/c2010br-02.pdf

U.S. Department of Labor. (n.d.-a). 1205-0453: The National Agricultural Workers Survey, Part B, Collection of information employing statistical methods. Retrieved from http://doleta.gov/agworker/pdf/ Statistical $\% 20$ Methods $\% 20$ of $\% 20$ the $\% 20$ National $\% 20$ Agricultural $\% 20$ Workers $\% 20$ Survev.pdf

U.S. Department of Labor. (n.d.-b). NAWS public access data: Fiscal years 1989-2009, Retrieved from http://wdr.doleta.gov/directives/attach/TEN/ten 2010/TEN_21-10_Att1.pdf

Verdaguer, M. E. (2009). Class, ethnicity, gender and Latino entrepreneurship. New York: Routledge.

Wang, Q., \& Li, W. (2007). Entrepreneurship, ethnicity and local contexts: Hispanic entrepreneurs in three U.S. southern metropolitan areas. GeoJournal, 68(2), 167-182. http://dx.doi.org/10.1007/s10708-0079081-0

World Bank. (2015). Doing business: Measuring business regulations. Retrieved October 29, 2015, from http://www.doingbusiness.org/

Zarrugh, L. (2007). From workers to owners: Latino entrepreneurs in Harrisonburg, Virginia. Human Organization, 66(3), 240-248. http://dx.doi.org/ $\underline{10.17730 / \text { humo.66.3.6048634r4402v675 }}$ 